\title{
Efektivitas Penggunaan Model Pembelajaran Berbasis Masalah (PBM) terhadap Hasil Belajar Fisika Siswa SMAN 9 Lubuklinggau
}

\author{
Eka Maryam \\ Prodi Teknik Informatika STMIK Musi Rawas, Sumatera Selatan \\ Email: ekamaryam966@gmail.com
}

\begin{abstract}
[The Effectiveness of Using a Model Problem-based Learning (PBL) to the Results of Physics Learning on High School Students 9 Lubuklinggau]. The objective of this study was to determine the effectiveness of the use of problem-based learning model. The research method used experiments with the form of Nonequivalent Control Group Design. The sample in this research is the students of class XI A and class XI B SMA N 9 Lubuklinggau City which amounted to 50 students. The technique of collecting data in this research is a test. The test is in the form of pretest and finally test (posttest). The purpose of holding initial and final tests to determine the effectiveness of Physics learning with PBM model and conventional learning. The test instrument that was made before the test was tested was done by panelists test using Intracorelation class coefficient (ICC). Data analysis technique used in this research is t-test. The results showed that there are differences in student learning outcomes taught with ProblemBased Learning model (PBM) with students taught with conventional learning model. The difference can be seen in the result of $t$-test which yields $t$-count $>t$-table $(3,98>2.01)$. The effectiveness of using the PBM model in the experimental class is $13.5 \%$ better than in the control class.
\end{abstract}

Keywords: Effectiveness; model; PBL; learning outcomes.

\begin{abstract}
ABSTRAK
Penelitian ini bertujuan untuk mengetahui efektivitas penggunaan model pembelajaran berbasis masalah (PBM). Metode penelitaian yang digunakan adalah eksperimen dengan bentuk Nonequivalent Control Group Desig. Sampel dalam penelitian ini adalah siswa kelas XI A dan kelas XI B SMA N 9 Kota Lubuklinggau yang berjumlah 50 orang siswa. Teknik pengumpulan data pada penelitian ini berupa tes. Tes tersebut berupa tes awal (pretest) dan tes akhir (posttest). Tujuan diadakannya tes awal dan tes akhir untuk mengetahui efektivitas pembelajaran Fisika dengan model PBM dan pembelajaran konvensional. Instrumen tes yang dibuat sebelum diuji cobakan dilakukan uji panelis menggunakan Intracorelation class coefisien (ICC). Teknik analisis data yang digunakan dalam penelitian ini yaitu uji-t. Adapun hasil penelitian menunjukan terdapat perbedaan hasil belajar siswa yang diajarkan dengan model Pembelajaran Berbasis Masalah (PBM) dengan siswa yang diajarkan dengan model pembelajaran konvensional. Perbedaan tersebut dapat dilihat pada hasil uji-t yang menghasilkan nilai $t_{\text {hitung }}>t_{\text {tabel }}(3,98>2,01)$. Efektivitas penggunaan model PBM pada kelas eksperimen yaitu sebesar $13.5 \%$ lebih baik dibandingkan pada kelas kontrol.
\end{abstract}

Kata kunci: Efektivitas; model; PBM; hasil belajar.

\section{PENDAHULUAN}

Gerakan reformasi pendidikan saat ini membutuhkan persiapan calon guru dan guru bersertifikat untuk mengatasi beragam masalah kompleks yang muncul di kelas. Perubahan cara pandang terhadap siswa sebagai objek menjadi subjek dalam proses pembelajaran menjadi titik tolak ditemukannya berbagai pendekatan pembelajaran yang inovatif. Guru dituntut dapat memilih model pembelajaran yang dapat memacu semangat setiap siswa untuk secara aktif ikut terlibat dalam pengalaman belajarnya. Salah satu alternatif model pembelajaran yang bisa dikembangkan untuk keterampilan berpikir (penalaran, komunikasi, dan koneksi) siswa dalam memecahkan masalah adalah Pembelajaran Berbasis Masalah (PBM).

Pembelajaran Berbasis Masalah (PBM) adalah suatu pendekatan pembelajaran yang menggunakan masalah realitas sebagai titik awal pembelajaran dan sebagai konteks bagi siswa untuk belaanjar tentang berpikir kritis dan keterampilan pemecahan masalah serta untuk memperoleh pengetahuan dan konsep dari materi 
pelajaran (Yusof et al, 2011). Menurut (Sockalingam et al, 2012) ada lima sarat yang harus dipenuhi terkait masalah yang akan dijadikan pembelajaran yaitu 1) sejauh mana masalah mengarah ke formulasi tujuan pembelajaran yang dimaksudkan, 2) sejauh mana masalah akrab bagi siswa, 3) sejauh mana masalah mempengaruhi minat belajar siswa, 4) sejauh mana masalah mempromosikan pembelajaran kolaboratif, dan 5) sejauh mana masalah merangsang pemikiran kritis.

Model PBM menjadikan seorang guru sebagai fasilitator, sehingga guru dapat menggunakan masalah sehari-hari siswa yang berkaitan dengan gejala fisiska untuk dianalisis dan dipecahkan permsalahnya sebagai pembelajaran. Apabila guru dapat menjalankan fungsinya dengan baik maka tujuan pembelajaran dapat dicapai (Fahrudin, 2018. Menurut Sahyar et al. (2017) model PBM lebih efektif dalam meningkatkan kemampuan memecahkan masalah fisika siswa jika didukung dengan memberikan pelatihan yang berisi masalah fisika yang berkaitan dengan kehidupan sehari-hari, memberikan praktikum yang tepat untuk memecahkan masalah fisika, serta menyajikan masalah fisika yang mengharuskan siswa memecahkan masalah. Penelitian mengenai model pembelajaran berbasis masalah juga dilakukan oleh Susilawati et al (2018) dan didapatkan hasil bahwa terdapat peningkatan hasil belajar menggunakan model pembelajaran berbasis masalah pada konsep Perpindahan Kalor siswa kelas X-TKJ SMK Negeri 1 Bengkulu Tengah.

\section{Pengertian Belajar}

Belajar merupakan proses atau kegiatan peserta didik yang direncanakan, dilaksanakan, dan dievaluasi oleh guru secara sistematis agar peserta didik dapat belajar dalam situasi dan kondisi yang kondusif dan efektif serta dengan hasil yang lebih yang optimal sehingga tingkah laku peserta didik dapat berubah ke arah yang lebih baik (Maryam, 2018). Belajar merupakan suatu bentuk perubahan atau pertumbuhan dalam diri induvidu yang dinyatakan dalam cara-cara bertingkah laku karena pengalaman dan latihan. prinsip-prinsip belajar sebagai berikut:

- Siswa terlibatan langsung dalam belajar atau berpengalaman
- Keaktifan dalam belajar (membaca, mendengar, menulis, berlatih keterampilan, dan sebagainya).

- Adanya perhatian dan pemberian motivasi

- Pengulangan belajar atau berkelanjutan

- Adanya balikan dan penguatan

\section{Hasil Belajar}

Proses belajar memang kompleks, tetapi dapat juga dianalisa untuk mengetahui hasil belajar. Hasil belajar (scholastic achievement) adalah keseluruhan kecakapan dan hasil yang dicapai melalui proses belajar mengajar di sekolah yang dinyatakan dengan angka-angka atau nilai yang diukur dengan Tes Hasil Belajar (THB). Sedangkan menurut (Maryam, 2017) hasil belajar merupakan penilaian akhir dari proses dan pengalaman yang telah dilakukan berulang-ulang, dan tersimpan untuk jangka waktu lama atau bahkan tidak akan hilang sebab hasil belajar ikut membentuk pribadi siswa lebih baik lagi.

\section{Pengertian Model Pembelajaran}

Model-model pembelajaran biasanya
disusun berdasarkan prinsip atau teori pengetahuan. Para ahli menyusun model pembelajaran berdasarkan prinsip-prinsip pembelajaran, teori-teori psikologis, sosiologis, analisis sistem, atau teori-teori lain yang mendukung. Model pembelajaran berdasarkan teori belajar yang dikelompokan menjadi empat model pembelajaran. Model tersebut merupakan Pola umum prilaku pembelajaran untuk mencapai tujuan pembelajaran yang diharap.

Model pembelajaran adalah suatu rencana atau pola yang dapat digunakan untuk membentuk kurikulum (rencana pembelajaran jangka panjang), merancang bahan-bahan pembelajaran, dan membimbing pembelajaran dikelas atau yang lain (Rusman, 2010). Model pembelajaran dapat dijadikan pola pilihan, artinya para guru boleh memilih model pembelajaran yang sesuai dan efesien untuk mencapai tujuan pendidikannya.

\section{Model Pembelajaran Berbasis Masalah (PBM)}

Pembelajaran Berbasis Masalah (PBM) merupakan suatu pembelajaran yang dimulai dengan adanya masalah kemudian menjadikan 
masalah tersebut menjadi konteks bagi siswa untuk belajar serta untuk memperoleh pengetahuan (Maryam, 2017). Menurut (Simone, 2014) tujuan PBM terdiri dari konstruksi pengetahuan konseptual pedagogis, kolaborasi, dan kesadaran diri untuk belajar sepanjang hayat. Adapun karakteristik pembelajaran berbasis masalah adalah sebagai berikut :

- Permasalahan menjadi starting point dalam belajar;

- Permasalahan yang diangkat adalah permasalahan yang ada didunia nyata yang tidak tertstruktur.

- Permasalahan membutuhkan perspektif ganda (multiple perspective)

- Permasalahan, menantang pengetahuan yang dimiliki oleh siswa, sikap dan kompetensi yang kemudian membutuhkan identifikasi kebutuhan belajar dan bidang baru dalam belajar

- Belajar mengarah diri menjadi hal yang utama

- Pemanfaatan sumber pengetahuan yang beragam, penggunaannya, dan evaluasi sumber informasi merupakan proses yang ensesial dalam PBM

- Belajar adalah kolaboratif, komunikasi, dan komperatif

- Pengembangan keterampilan inquiry dan pemecahan masalah sama pentingnya dengan penguasaan isi pengetahuan untuk mencari solusi dari sebuah permasalahan

- Keterbukaan proses dalam PBM meliputi sintesis dan integrasi dari sebuah proses belajar

- PBM melibatkan evaluasi dan review pengalaman siswa dan proses belajar

Adapun peran guru didalam pembelajaran berbasis masalah (PBM), Guru harus menggunakan proses pembelajaran yang akan menggerakan siswa menuju kemandirian hidup dan belajar sepanjang hayat. Lingkungan belajar yang dibangun guru harus mendorong cara berpikir refleksi, evaluasi kritis, dan cara berpikir yang berdayagunakan. PBM adalah metode pengajaran yang memotivasi siswa untuk mencapai kesuksesan akademik (Rubiah, 2016). Sehingga guru harus memotivasi dan menjalankan perannya dalam menerapkan pembelajaran PBM. Peran guru yaitu: 1) bagaimana dapat merancang dan menggunakan permasalahan yang ada di dunia nyata, sehingga siswa dapat menguasai hasil belajar, 2) bagaimana bisa menjadi pelatih siswa dalam proses pemecahan masalah, pengarahan diri dan belajar dengan teman sebaya, 3) dan bagaimana siswa memandang diri mereka sendiri sebagai pemecah masalah yang aktif. Tahap-tahap Model Pembelajaran Berbasis Masalah adalah sebagai berikut, seperti yang ditunjukan pada Tabel 1 .

Tabel 1. Tahap-tahap model pembelajaran berbasis masalah (PBM)

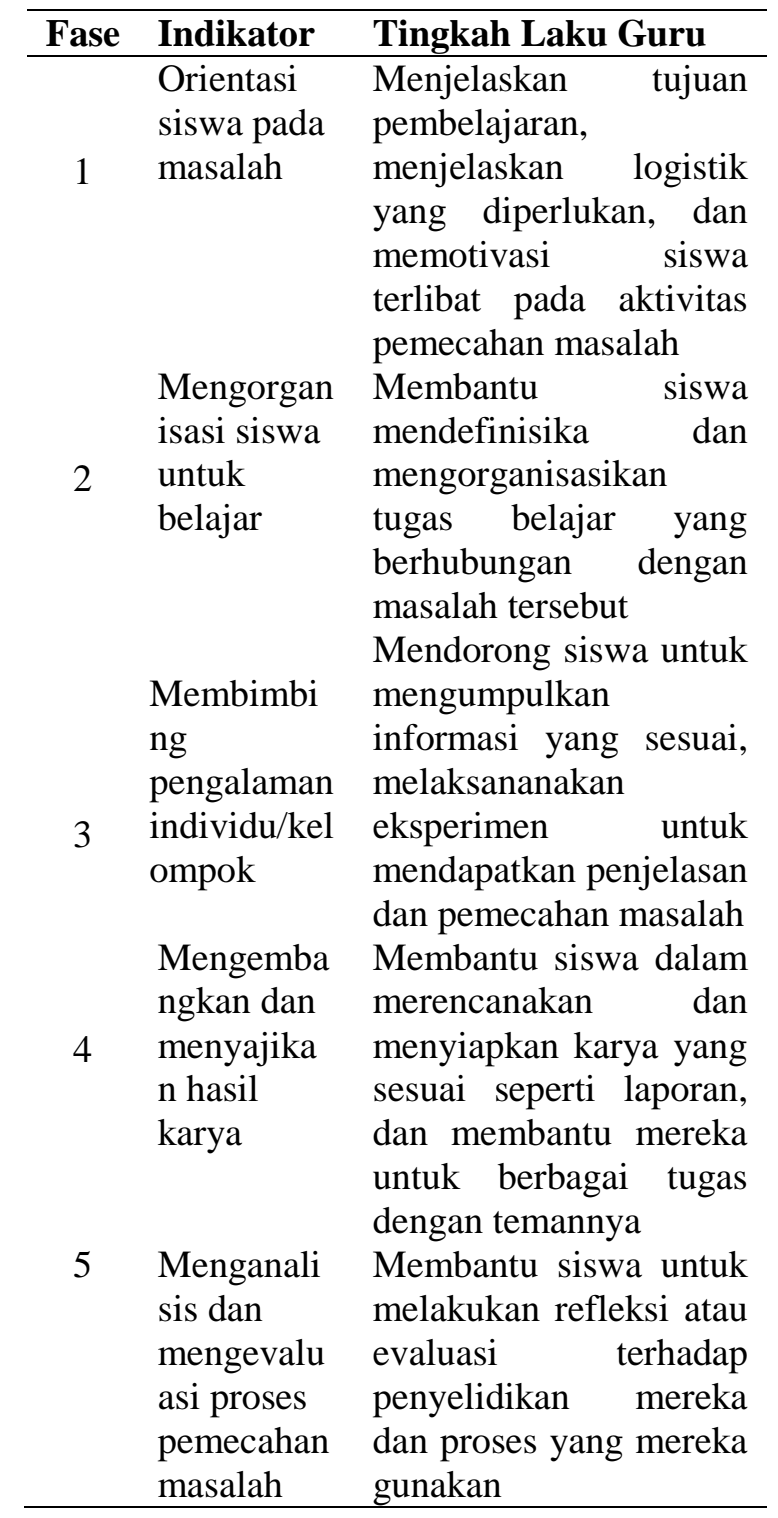

\section{METODE PENELITIAN}

Jenis penelitian yang akan digunakan dalam penelitian ini yaitu penelitian eksperimen. Desain 
penelitian yang digunakan adalah Nonequivalent Control Group Design (Sugiyono, 2010).

Dengan cara memilih dua kelas yang homogen kemudian diberi pretest untuk mengetahui pengetahuan awal siswa kelas eksperimen (A) dan kelas kontrol (B). Kedua kelas diberikan perlakuan yang berbeda seperti ditunjukkan dalam Tabel 2.

Tabel 2. Nonequivalent Control Group Design

\begin{tabular}{cccc}
\hline Kelas & Pretest & Perlakuan & Posttest \\
\hline $\mathrm{A}$ & $\mathrm{O}_{1}$ & $\mathrm{X}_{1}$ & $\mathrm{O}_{2}$ \\
$\mathrm{~B}$ & $\mathrm{O}_{3}$ & $\mathrm{X}_{2}$ & $\mathrm{O}_{4}$ \\
\hline
\end{tabular}

Keterangan:

$\mathrm{X}_{1}=$ Pembelajaran PBM

$\mathrm{X}_{2}=$ Pembelajaran Konvensional

$\mathrm{O}_{1}=$ Nilai pretest kelas $\mathrm{X}_{1}$

$\mathrm{O}_{2}=$ Nilai posttest kelas $\mathrm{X}_{1}$

$\mathrm{O}_{3}=$ Nilai Pretest Kelas $\mathrm{X}_{2}$

$\mathrm{O}_{4}=$ Nilai Posttest Kelas $\mathrm{X}_{2}$

\section{Populasi dan Sampel}

Penelitian ini dilakukan di Kota Lubuklinggau dan tempat penelitiannya di SMA N 9 Kota Lubuklinggau. Populasi dalam penelitian ini adalah seluruh siswa kelas XI SMA N 9 Kota Lubuklinggau. Sampel dalam penelitian ini adalah siswa kelas XI A dan kelas XI B yang berjumlah 50 orang siswa. Masing masing siswa pada kelas XIA dan XIB diajar oleh guru yang sama dan dengan kurikulum yang sama. Teknik penentuan sampel dalam penelitian ini yaitu berdasarkan teknik Sampling Purpose (Sugiyono, 2010).

\section{Teknik Pengumpulan Data}

Teknik pengumpulan data pada penelitian ini berupa tes. Tes tersebut berupa tes awal (pretest) dan tes akhir (posttest). Tujuan diadakannya tes awal dan tes akhir untuk mengetahui efektivitas pembelajaran Fisika dengan model pembelajaran PBM dan pembelajaran konvensional. Pada instrumen tes yang dibuat sebelum di uji cobakan dilakukan uji panelis. Uji Panelis bertujuan untuk menentukan tingkat keterbacaan dari setiap butir tes (Face validity). Uji validisi terhadap instrumen tes yang digunakan dalam penelitian ini adalah validisi isi. Pengembangan validasi butir tes di validasi oleh 3 orang ahli (Panelis) dan diujicobakan pada 75 siswa SMA N 9 Kota Lubuklinggau dikelas yang berbeda Uji panelis menggunakan Intracorelation class coefisien (ICC). Adapun persamaaan ICC sebagai berikut. :

$$
\text { ICC }=\frac{\sigma^{2} \text { butir }}{\sigma^{2} \text { butir }+\sigma^{2} \text { panelis }+\sigma^{2} \text { error }}
$$

Keterangan :

$$
\begin{aligned}
& \text { ICC }= \begin{array}{l}
\text { Koefisien Intracorelation class } \\
\text { coefisien }
\end{array} \\
& \sigma_{\text {error }}^{2}= \text { Varians error } \\
& \sigma^{2} \text { panelis }= \text { Varians Panelis } \\
& \sigma^{2} \text { butir }=\text { Varians butir }
\end{aligned}
$$

Pedoman untuk melakukan penilaian oleh ketiga panelis (Raters) digunakan suatu rubrik yang terdiri dari 4 aspek penilaian yaitu :

- Materi soal sesuai silabus dan aspek berfikir menurut taxonomy bloom,

- Bentuk gambar dan soal dirumuskan secara jelas,

- Bahasa yang digunakan sesuai dengan kaidah EYD, mudah dipahami dan jelas,

- Soal dan kunci soal benar dan disertai dengan lima kriteria penilaian yaitu nilai nol jika tidak memenuhi 4 aspek penilaian, nilai satu jika memenuhi 1 aspek penilaian, nilai dua jika memenuhi 2 aspek penilaian, nilai tiga jika memenuhi 3 aspek penilaian dan nilai empat jika memenuhi 4 aspek penilaian

Setelah dilakukan uji panelis pada instrumen yang dibuat kemudian sebelum pengambilan data tes, terlebih dahulu dilakukan uji coba instrumen yaitu uji validitas, reabilitas, daya pembeda dan uji taraf kesukaran.

\section{Teknik Analisis Data}

Data yang diperoleh melalui Nonequivalent Control Group Design dianalisis dengan uji normalitas dan uji homogenitas sebelum dilakukan pengujian hipotesis. Uji homogenitas dilakukan dilakukan dengan menggunakan program SPSS versi 17 dengan uji Untransformed pada taraf signifikasi 5\%. Kriteria uji homogenitas adalah apabila angka signifikansi > 0,05, maka data homogen dan jika angka signifikansi < 0,05, maka data tidak homogen.

Sedangkan pengujian normalitas data digunakan untuk melihat distribusi data (sampel) yang digunakan dalam penelitian. Uji normalitas yang digunakan dalam penelitian ini adalah uji 
Kolmogorov-Smirnov dan uji Shapiro-Wilk pada taraf signifikansi $\alpha$ : 0,05 dengan mengunakan bantuan program SPSS versi 17. Kriteria data untuk distribusi normal atau tidak adalah angka signifikansi >0,05, maka data berdistribusi normal dan jika angka signifikansi $<0,05$, maka data tidak berdistribusi normal.

\section{Hipotesis Statistik}

Dari hasil peneltian yang telah dilakukan yaitu data pretest dan data postest pada kelas kontrol dan kelas eksperimen merupakan data normal dan homogen maka dilanjutkan dengan pengujian hipotesis. Analisis yang digunakan dalam pengujian ini yaitu uji- $t$. Tujuan dari uji- $t$ ini adalah untuk membandingkan (membedakan) apakah kedua data (variabel) sama atau berbeda. Pengujian dilakukan dengan $\alpha=0,05$ dengan derajat bebas $\mathrm{n}_{1+} \mathrm{n}_{2}-2$. Uji- $t$ ( $\left.\mathrm{t}_{\text {-test }}\right)$ dua sampel:

$$
\mathrm{t}_{\text {hitung }}=\frac{\overline{X_{1}}-\overline{X_{2}}}{\sqrt{\frac{s_{1}^{2}}{n_{1}}+\frac{s_{2}^{2}}{n_{2}}}}
$$

Keterangan:

$\overline{X_{1}}=$ rata-rata sampel kelompok 1

$\overline{\mathrm{X}_{2}}=$ rata-rata sampel kelompok 2

$\mathrm{S}=$ Simpangan baku populasi perbedaan ratarata

kriteria pengujian: jika $-t_{\text {tabel }} \leq t_{\text {hitung }} \leq t_{\text {tabel }}$, maka Ho diterima dan $\mathrm{H}_{1}$ ditolak

\section{HASIL DAN PEMBAHASAN}

Data hasil penilaian dari ketiga panelis dianalisis menggunakan SPSS versi 17 untuk menentukan koefisien internal konsisten antar panelis (Intraclass Correlation Coeficient atau ICC). Adapun hasil analisis dari penilian panelis ditampilkan pada Tabel 3.

Tabel 3. Hasil Intraclass Correlation Coeficient (ICC) Tes Oleh Panelis

\begin{tabular}{lcccccc}
\hline $\begin{array}{c}\text { Sumber } \\
\text { Varian }\end{array}$ & $\begin{array}{c}\text { Sum of } \\
\text { Square } \\
(\boldsymbol{S S})\end{array}$ & $\begin{array}{c}\text { Degree } \\
\text { of } \\
\text { Freedo } \\
\boldsymbol{m}\end{array}$ & $\begin{array}{c}\text { Mean } \\
\text { Of } \\
\text { Square }\end{array}$ & ICC & $\mathbf{F}_{\text {hitung }}$ & $\mathbf{F}_{\text {tabel }}$ \\
\hline Panelis & 0,044 & 2 & 0,022 & & & \\
Butir & 5,244 & 14 & 0,375 & 0,84 & 1,000 & 3,182 \\
Error & 0,622 & 28 & 0,022 & & & \\
Total & 5,911 & 44 & & & & \\
\hline
\end{tabular}

Dari Tabel 3 menunjukkan bahwa hasil perhitungan Two Way Anova yang disubtitusikan ke persamaan ICC diperoleh nilai ICC sebesar 0,84 , ini menunjukkan bahwa instrumen penelitian (tes) memiliki stabilitas yang tinggi karena nilai ICC antar pengukuran $\geq 0,80$ (Norman dalam Murti, 2011).

\section{Hasil Tes Awal (Pretes)}

Tes awal dilakukan pada kelas kontrol dan eksperimen yang bertujuan untuk mengetahui kemampuan awal siswa sebelum diberikan pembelajaran (perlakuan). Sebelum melakukan uji beda ( $t$-test) untuk Fmengetahui apakah ada atau tidak perbedaan nilai data tes awal dari kedua kelas, telah dilakukan diuji normalitas dan homogenitas untuk memenuhi persyaratan uji hipotesis penelitian. Hasil uji normalitas data pretes mengunakan SPSS versi 17 ditampilkan pada Tabel 4.

Tabel 4. Hasil Uji Normalitas Tes Awal (Pretest) Kelas Kontrol dan Kelas Eksperimen

\begin{tabular}{|c|c|c|c|c|}
\hline \multirow{2}{*}{ Kelas } & \multicolumn{2}{|c|}{$\begin{array}{l}\text { Kolmogorov- } \\
\text { Smirnov }\end{array}$} & \multicolumn{2}{|c|}{ Shapiro-Wilk } \\
\hline & df & Signifikansi & Df & Signifikansi \\
\hline Kontrol & & $0,20^{*}$ & & 0,53 \\
\hline Eksperimen & 25 & $0,20^{*}$ & 25 & 0,41 \\
\hline
\end{tabular}

Tabel 4 menunjukkan bahwa nilai signifikansi Kolmogorov-Smirnov sebesar 0,20 pada kelas kontrol dan kelas eksperimen, sedangkan nilai signifikansi Shapiro-Wilk sebesar 0,53 pada kelas kontrol dan 0,41 pada kelas eksperimen. Nilai signifikansi kedua kelas tersebut lebih besar dari taraf signifikansi 0,05. Sehingga distribusi data tes awal pada kelas kontrol dan kelas eksperimen dapat dianggap terdistribusi normal.

Sedangkan hasil uji homogenitas data pretes menggunakan uji untransformed dengan taraf signifikansi 0,05 untuk kedua kelas dapat dilihat pada Tabel 5. Berdasarkan Tabel 5 Based on Mean nilai Levene Statistic adalah 0,117 dengan signifikansi 0,734 sehingga nilai ini > taraf signifikansi 0,05 yang menyatakan bahwa data pretest kelas kontrol dan pretest kelas eksperimen dapat diasumsikan bersifat homogen atau mempunyai varian yang sama. 
Tabel 5. Hasil Homogenitas Pretest Kelas Kontrol dan kelas Eksperimen

\begin{tabular}{lcccc}
\hline Pretest & $\begin{array}{l}\text { Levene } \\
\text { Statistic }\end{array}$ & df1 & df2 & Sig. \\
\hline $\begin{array}{l}\text { Based } \\
\text { on }\end{array}$ & 0,117 & 1 & 48 & 0,734 \\
Mean & & & & \\
\hline
\end{tabular}

Setelah data pretest kelas kontrol dan eksperimen terdistribusi normal dan homogen, maka dilanjutkan dengan uji beda. Hal ini dimaksudkan untuk mengetahui apakah terdapat perbedaan data tes awal di kelas kontrol dan kelas eksperimen. Hasil uji t-Test untuk kelas kontrol dan kelas eksperimen dapat dilihat pada Tabel 6.

Tabel 6. Uji Beda Pretest Kelas Kontrol dan Kelas Eksperimen $(\mathrm{N}=25)$

\begin{tabular}{cccc}
\hline Kelas & $\boldsymbol{t}$-hitung & $\boldsymbol{t}$-hitung & Signifikansi \\
\hline Kontrol & 0,652 & 2,01 & 0,62 \\
Eksperimen & & & \\
\hline
\end{tabular}

Dari Tabel $6 t$-hitung $<t$-tabel $(0,65<$ 2,01) dengan taraf signifikansi $0,62>0,05$ Disimpulkan bahwa data pretest kelas kontrol dan eksperimen tidak ada beda. Maka, dapat dilanjutkan ke perlakuan.

\section{Hasil Test Akhir (Posttes)}

Setelah dilakukan pretes dan didapatkan data hasil uji t pretes yang menunjukan bahwa pada kelas kontrol dan kelas eksperimen tidak ada beda maka, selanjunya pada kelas eksperimen diberikan perlakuan pembelajaran modem PBM. Sedangkan pada kelas kontrol tetap diajar menggunakan metode mngajar seperti biasanya. Setelah tahap pengajaran selesai tes akhir (posttest) diberikan kepada siswa-siswa di kedua kelas. Data-data tes yang berasal dari kelas eksperimen dan kelas kontrol di lakukan uji normalitas dan homogenitas. Kedua uji dilakukan untuk memenuhi persyaratan uji $t$-tes. Hasil uji normalitas data posttes mengunakan SPSS versi 17 ditampilkan pada Tabel 7.

Berdasarkan Tabel 7 nilai signifikansi Kolmogorov-Smirnov pada kelas eksperimen dan kelas kontrol masing-masing adalah 0,22. Sedangkan nilai signifikansi Shapiro-Wilk adalah 0,39 pada kelas eksperimen dan 0,50 pada kelas kontrol. Nilai tersebut lebih dari besar dari taraf signifikansi 0,05. Disimpulkan bahwa data posttest kelas eksperimen dan kelas kontrol terdistribusi normal.

Tabel 7 Uji Normalitas Data Tes Akhir pada Kelas Eksperimen dan Kelas Kontrol

\begin{tabular}{lcccc}
\hline \multicolumn{1}{c}{ Kelas } & $\begin{array}{c}\text { Kolmogorov- } \\
\text { Smirnova }^{\text {a }}\end{array}$ & Shapiro-Wilk \\
& df & $\begin{array}{c}\text { Signifikans } \\
\text { i }\end{array}$ & Df & $\begin{array}{c}\text { Signifika } \\
\text { nsi }\end{array}$ \\
\hline $\begin{array}{l}\text { Eksperimen } \\
\text { Kontrol }\end{array}$ & 25 & $0,22^{*}$ & & 0,39 \\
\hline
\end{tabular}

Sedangkan hasil uji homogenitas data posttes menggunakan uji untransformed dengan taraf signifikansi 0,05 untuk kedua kelas dapat dilihat pada tabel 8

Tabel 8. Hasil Uji Homogenitas Peningkatan Nilai Pretest dan Posttest Kelas Eksperimen dan Kelas Kontrol

\begin{tabular}{lcccc}
\hline Posttest & $\begin{array}{l}\text { Levene } \\
\text { Statistic }\end{array}$ & df1 & df2 & Sig. \\
\hline $\begin{array}{l}\text { Based on } \\
\text { Mean }\end{array}$ & 1,667 & 1 & 48 & 0,203 \\
\hline
\end{tabular}

Berdasarkan Tabel 8 Based on Mean nilai Levene Statistic 1,667 dengan Signifikansi 0,203, nilai signifikansi ini >0,05, menyatakan bahwa data peningkatan nilai pretest dan posttest kelas kontrol dan kelas eksperimen adalah homogen atau mempunyai varian yang sama.

Setelah dilakukan uji prasyarat analisis, data yang didapatkan untuk pretest dan posttest kelas eksperimen dan kelas kontrol adalah terdistribusi normal dan variannya homogen. Oleh karena itu uji hipotesis yang dilakukan adalah uji- $t$ dengan menggunakan Independent Samples Test. Data peningkatan nilai pretest dan Posttest kelas kontrol dan kelas eksperimen dapat dilihat pada Tabel 9.

Tabel 9. Uji Beda Pretest Kelas Kontrol dan Kelas Eksperimen $(\mathrm{N}=25)$

\begin{tabular}{cccc}
\hline Kelas & $\boldsymbol{t}$-hitung & $\boldsymbol{t}$-hitung & Signifikansi \\
\hline Kontrol & 3,98 & 2,01 & 0,007 \\
Eksperimen & & & \\
\hline
\end{tabular}


Berdasarkan Tabel 9 Nilai $t_{\text {hitung }}>t_{\text {tabel }}$ $(3,98>2,01)$ dari hasil tersebut menunjukkan bahwa $\mathrm{H}_{0}$ ditolak yang artinya terdapat perbedaan hasil belajar siswa yang diajarkan dengan model pembelajaran PBM dengan siswa yang diajarkan dengan model pembelajaran konvensional. Nilai peningkatan kelas kontrol dan kelas eksperimen divisualisasikan pada Gambar 1.

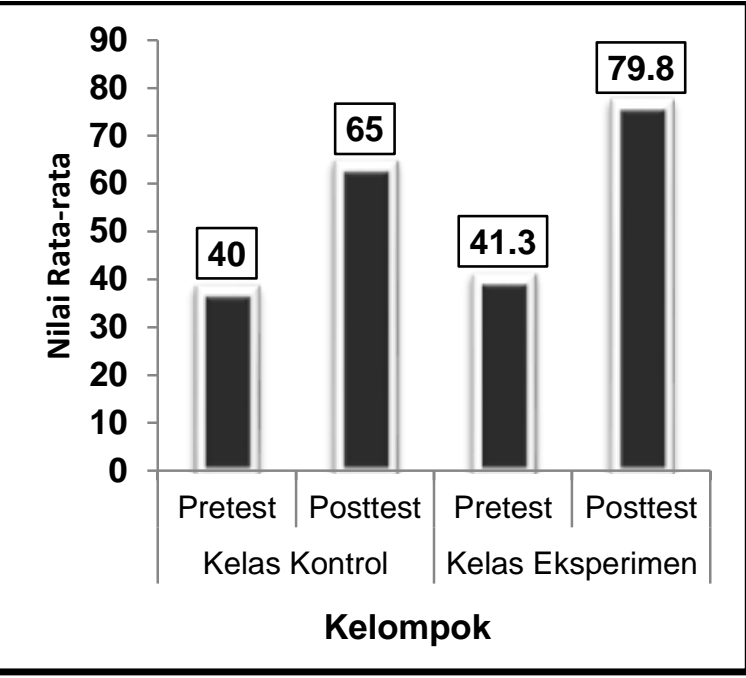

Gambar 1. Grafik Peningkatan Nilai Kelas Kontrol dan Kelas Eksperimen

Grafik pada Gambar 1 menunjukkan perbedaan nilai sebelum dan sesudah di berikan perlakuan yaitu adanya peningkatan nilai di kelas kontrol maupun di kelas eksperimen. Rata-rata peningkatan nilai pada kelas eksperimen dengan menggunakan model pembelajaran PBM adalah 38,5 . Sedangkan peningkatan rata-rata nilai kelas kontrol yang diberikan model pembelajaran konvensional adalah 25,0. Peningkatan nilai hasil belajar (kognitif) pada kelas eksperimen lebih tinggi dibandingkan dengan kelas kontrol. Selisih perbedaan rata-rata nilai kelas eksperimen dan kontrol adalah 13.5 atau $13.5 \%$ dari nilai maksimumnya.

\section{KESIMPULAN}

Terdapat perbedaan hasil belajar siswa yang diajarkan dengan model Pembelajaran Berbasis Masalah (PBM) dengan siswa yang diajarkan dengan model pembelajaran konvensional. Perbedaan tersebut dapat dilihat pada hasil uji-t yang menghasilkan nilai $t_{\text {hitung }}>t_{\text {tabel }}$ $(3,98>2,01)$. Efektivitas penggunaan model PBM pada kelas eksperimen yaitu sebesar $13.5 \%$ lebih tinggi dibandingkan pada kelas kontrol.

\section{DAFTAR PUSTAKA}

Fahrudin, A. 2018. Development of Physics Summary Book as a Smartphone-Based Application and Its Effect on Elasticity Learning Achievement. Physics Education Journal, 1(1). 22-33.

Maryam, E. 2017. Pengaruh menggunakan model PBL (Problem Based Learning) terhadap hasil belajar IPA Fisika SMP N 7 Kota Bengkulu. Jurnal Riset \& Kajian Pendidikan Fisika. 4(1), 18-21.

Maryam, E. 2018. The Effect of TGT Cooperative Learning on Student Learning Achievement Physics Class XI SMAN 1 Tugumulyo, Physics Education Journal. 1(1), 34-42.

Murti, B. 2011. Validitas dan Reliabilitas Penelitian. Martikulasi Program Studi Doktoral: Fakultas Kedokteran UNS.

Rubiah, M. 2016. Implementation of Problem Based Learning Model in Concept Learning Mushroom as a Result of Student Learning Improvement Efforts Guidelines for Teachers. Journal of Education and Practice. 7(22), 26-30.

Rusman. 2010. Model-model pembelajaran mengembangkan proffesionalisme guru. Jakarta: PT Rajagrafindo Persada.

Sahyar, Ridwan, A., \& Malau, T. 2017. The Effect of Problem Based Learning (PBL) Model and Self Regulated Learning (SRL) toward Physics Problem Solving Ability (PSA) of Students at Senior High, American Journal of Educational Research, 5(3), 279283.

Simone, D. C. 2014. Problem-Based Learning in Teacher Education: Trajectories of Change, International Journal of Humanities and Social Science, 4( 12), 17-29.

Sockalingam, N., Rotgans, J., \& Schmidt, H. J. 2012. Assessing the Quality of Problems in Problem-Based Learning. International Journal of Teaching and Learning in Higher Education 24 (1), 43-51.

Sugiyono, 2010, Penelitian Pendidikan. Bandung: Alfabeta.

Susilawati, Mayub, A., Farid, M. 2018. Menghitung nilai emisivitas warna 
menggunakan miniatur ruang berbentuk silinder sebagai media pembelajaran fisika. PENDIPA Journal of Science Education. 2(2), 135-141.

Yusof, M. K., Helmi, A. S., Jamaludin, J. M., \& Harun, F. N. 2011. Cooperative Problem-
Based Learning (CPBL) A Practical PBL Model for a Typical Course, International Journal of Emerging Technologies in Learning (iJET). 6(3), 12-20. 